\title{
PLASMAAS AN INDICATOR OF BONE FLUORIDE LEVELS IN RATS CHRONICALLY EXPOSED TO FLUORIDE
}

\author{
PLASMA COMO UM INDICADOR DOS NÍVEIS DE FLÚOR NO OSSO EM RATOS EXPOSTOS \\ CRONICAMENTE AO FLÚOR
}

Juliane Guimarães de CARVALHO ${ }^{1}$, Rodrigo Cardoso de OLIVEIRA², Marília Afonso Rabelo BUZALAF ${ }^{3}$

1- DDS, MSc, Department of Biological Sciences, Bauru Dental School, University of São Paulo, Brazil.
2- DDS, MSc, PhD, Assistant Professor, Department of Biological Sciences, Bauru Dental School, University of São Paulo, Brazil.
3- DDS, MSc, PhD, Associate Professor, Department of Biological Sciences, Bauru Dental School, University of São Paulo, Brazil.

Corresponding address: Department of Biological Sciences, Bauru Dental School, University of São Paulo, Alameda Octávio Pinheiro Brisolla, 9-75, Cep.: 17012-901, Bauru, SP, Brazil. Phone:+55-14-32358246 - Fax:+55-14-32271486 - e-mail: mbuzalaf@fob.usp.br

Received: June 06, 2005 - Modification: January 26, 2006 - Accepted: May 17, 2006

\begin{abstract}
$O$

bjective: This study evaluated the use of plasma, bone surface (periosteal) and whole bone as biomarkers of chronic fluoride (F) exposure. Methods: Forty male Wistar rats were assigned to 4 groups ( $\mathrm{n}=10 / \mathrm{gr}$ ) that differed according to the $\mathrm{F}$ concentration they received in the drinking water. Groups 1, 2, 3 and 4 received water containing 0 (control), 5, 15, and $50 \mathrm{mg}$ $\mathrm{F} / \mathrm{L}$, respectively. The rats were killed at 120 days of age. Plasma and femur were collected and analyzed for fluoride with the ion specific electrode by the direct method or after hexamethyldisiloxane-facilitated diffusion. Data were tested for statistically significant differences by ANOVA and linear regression ( $\mathrm{p}<0.05)$. Results: Mean $( \pm \mathrm{SE})$ plasma F concentrations ranged from $0.030 \pm 0.002$ to $0.187 \pm 0.013(\mathrm{mg} / \mathrm{mL})$. The concentrations in surface and whole bone ranged from $610 \pm 32$ to 4,693 222; and $647 \pm 22$ to $3,439 \pm 134 \mu \mathrm{g} / \mathrm{g}$, respectively. The surface/whole $\mathrm{F}$ concentration ratios were $0.941,1.414,1.173$ and 1.377, for groups 1, 2, 3 and 4 respectively. For plasma and whole bone, the difference among all groups was statistically significant, except for group 2 compared to group 1. For bone surface, all groups differed from each other except for group 2 compared to group 3. A significant positive correlation was found between bone surface and whole bone $F\left(r^{2}=0.94\right)$, as well as between plasma and bone surface $\left(r^{2}=0.71\right)$ and plasma and whole bone $\left(r^{2}=0.74\right)$. Conclusions: Data suggest that both bone surface and whole bone are suitable biomarkers of chronic $\mathrm{F}$ exposure in rats and plasma may be used as indicator of bone fluoride levels. Uniterms: Fluoride; Bone; Plasma; Biomarkers.
\end{abstract}

\section{RESUMO}

bjetivos: Este estudo avaliou o uso do plasma, superfície óssea e osso total como biomarcadores da exposição crônica ao flúor em ratos. Métodos: Quarenta ratos Wistar machos foram divididos em 4 grupos ( $\mathrm{n}=10 / \mathrm{gr}$ ) que diferiram de acordo com a concentração de flúor presente na água de beber. Os grupos 1, 2, 3 e 4 receberam água contendo 0, 5, 15 e $50 \mathrm{mg}$ F/L, respectivamente. Os ratos foram mortos ao completarem 120 dias. O plasma e os fêmures foram coletados e a concentração de flúor foi analisada com um eletrodo específico pelo método direto para a superfície do fêmur e após difusão facilitada por HMDS para o osso total e o plasma. Os dados foram analisados por ANOVA e regressão linear ( $<<0,05)$. Resultados: A média

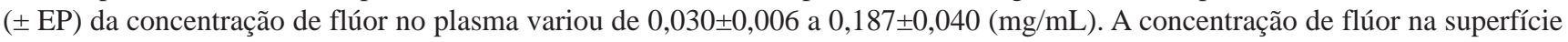
e no osso total variou de $610 \pm 103$ a $4693 \pm 703$ e $647 \pm 69$ a $3439 \pm 423(\mathrm{mg} / \mathrm{g})$, respectivamente. A proporção entre a concentração de flúor na superfície óssea e osso total foi de 0,941, 1,414, 1,173 e 1,377, para os grupos 1, 2, 3 e 4 respectivamente. Para o plasma e osso total, a diferença entre todos os grupos foi estatisticamente significante, exceto para o grupo 2 quando comparado com o grupo 1. Para a superfície óssea só não houve diferença entre o grupo 2 quando comparado com o grupo 3. Houve correlação positiva significante entre a concentração de flúor presente na superfície óssea e no osso total ( $\left.\mathrm{r}^{2}=0,94\right)$, tão bem como entre o plasma e a superfície óssea $\left(r^{2}=0,71\right)$ e o plasma e o osso total $\left(r^{2}=0,74\right)$. Conclusões: Os dados sugerem que tanto a superfície óssea quanto o osso total são bons indicadores da exposição crônica ao flúor em ratos e o plasma pode ser utilizado como um indicador dos níveis de flúor.

Unitermos: Flúor; Osso; Plasma; Biomarcadores. 


\section{INTRODUCTION}

The metabolism of fluoride in laboratory animals and humans is characterized by rapid and extensive absorption from the gastrointestinal tract, distribution to all soft tissues in which the intracellular-to-extracellular concentration ratios vary according to the magnitude of the $\mathrm{pH}$ gradients across cell membranes, extensive but not irreversible uptake by calcified tissues which contain $99 \%$ of the fluoride in the body, and rapid excretion in the urine ${ }^{12}$. From the pharmacokinetic point of view, plasma is regarded as the central compartment because it is this fluid into which and from which fluoride must pass for distribution and excretion. Thus, plasma fluoride concentrations reflect the concentrations elsewhere in the body including those in bone $e^{6,8,10,12}$.

At a 1999 dental workshop in Bethesda, Maryland, USA, the participants proposed an international research agenda on fluoride (F). One of the topics was the identification of $\mathrm{F}$ biomarkers that are easy to collect and analyze, in order to determine the body burden and to measure acute and chronic F exposure in relation to bone $F$ levels and fluoride in plasma, ductal saliva, dentin and fingernails ${ }^{4}$.

The uptake of $\mathrm{F}$ from the extracellular fluids by bone in the short-term occurs largely on the periosteal and endosteal surfaces where it is firmly but not irreversibly bound. Thus, the analysis of bone surface $\mathrm{F}$ has the potential of being a more reliable biomarker for acute $\mathrm{F}$ exposure than whole bone $e^{1,2,3}$. In the case of chronic exposure to fluoride, however, it would be expected that both bone surface and whole bone fluoride concentrations would have the same potential as biomarkers of exposure to fluoride and would be similarly related to plasma fluoride levels. Thus, this study was designed to test this hypothesis

\section{MATERIALS AND METHODS}

Forty male Wistar rats were obtained from the Central Aninal Laboratory of Bauru Dental School and received as weanlings. They were assigned to 4 groups $(n=10 / g r)$ that differed according to the $\mathrm{F}$ concentration they received in the drinking water. Groups 1, 2, 3 and 4 received water containing 0 (control), 5, 15 and $50 \mathrm{mg} \mathrm{F/L} \mathrm{(as} \mathrm{NaF),}$ respectively. The rat's diet contained $22-26 \mu \mathrm{g} \mathrm{F/g}$.

A blood sample was drawn by cardiac puncture when the rats were 120 days old and while under general anesthesia. Each rat was then killed by excessive anesthesia. The right femur was removed from each rat, cleaned of soft tissue with gauze and dried for $24 \mathrm{~h}$ at $90^{\circ} \mathrm{C}$.

\section{Fluoride analysis: bone surface}

The mid-diaphysis of the femur was sectioned transversely to obtain a specimen with $1.0 \mathrm{~cm}$ in length. The cut edges were sealed with dental wax. A circular hole (2.4 $\mathrm{mm}$ diameter) was punched in adhesive tape, which was applied firmly to the center of the bone specimen. The remaining surfaces of the bone were painted with acid- resistant nail varnish so that only a $4.52 \mathrm{~mm}^{2}$ surface area was exposed. The bone was then placed in a plastic test tube containing $0.50 \mathrm{~mL}$ of $0.50 \mathrm{M} \mathrm{HCl}$ and, after $15 \mathrm{~s}$ of being constantly agitated, the acid was buffered to $\mathrm{pH} 5$ by the addition of $0.50 \mathrm{~mL}$ of Total Ionic Strength Adjustment Buffer (TISAB) ${ }^{1}$ and the bone was removed from the solution. This solution was analyzed along with standards containing from 0.8 to $6.4 \mu \mathrm{g} \mathrm{F} / \mathrm{mL}$ using the ion-specific electrode (Orion model 9609). The $\mathrm{mV}$ readings were converted to $\mu \mathrm{g}$ F using a standard curve with a coefficient correlation of $\mathrm{r}^{3}$ 0.99. The weight of bone mineral removed was obtained by the colorimetric analysis of inorganic phosphorus ${ }^{7}$ in the acid assuming that its concentration in dry bone is $13.5 \%$. The fluoride concentration on the bone surface is expressed as $\mu \mathrm{g} \mathrm{F/g}$ bone (ppm). The remaining bone was ashed at $600^{\circ} \mathrm{C}$ overnight, after removing the nail varnish.

\section{Fluoride analysis: Plasma and bone ash}

F concentrations were determined after overnight hexamethyldisiloxane (HMDS)-facilitated diffusion (Taves ${ }^{9}$ ) as modified by Whitford ${ }^{12}$ using the ion-specific electrode (Orion Research, Model 9409) and a miniature calomel electrode (Accumet, \#13-620-79) both coupled to a potentiometer (Orion Research, Model EA 940).

Deionized water $(2.0 \mathrm{~mL})$ was placed in the bottom of a non-wettable diffusion dish (Falcon, 1007) along with the bone ash (5 mg) and plasma. The trapping solution, $50 \mu \mathrm{L}$ of $0.05 \mathrm{M} \mathrm{NaOH}$, was placed in three drops on the inside of the lid of the dish. The periphery of the lid was ringed with Vaseline and sealed to the bottom of the dish. Two mL of 3.0 $\mathrm{N} \mathrm{H}_{2} \mathrm{SO}_{4}$ saturated with HMDS were added to the bottom through a small hole previously burned into the lid with a soldering iron. The hole was immediately sealed with Vaseline. During the diffusion process, which continued overnight at room temperature, the solutions were swirled at $45 \mathrm{rpm}$ on a rotary shaker. The next day the lid was removed and inverted and the trapping solution was buffered to $\mathrm{pH}$ 5 with $25 \mu \mathrm{L}$ of $0.20 \mathrm{M}$ acetic acid. The final volume was then adjusted to $75 \mu \mathrm{L}$ by the addition of deionized water using a fixed volume pipettor. The $\mathrm{F}$ and reference electrodes were placed in contact with the solution with gentle agitation until a stable $\mathrm{mV}$ reading was obtained. F standards (containing 1.9, 3.8, 19 and $38 \mathrm{mg} F$ for bone ash and 0.5 1.0, 5.0 and $10.0 \mathrm{~nm} \mathrm{~F}$ for plasma) were prepared in triplicate and diffused in the same manner as the bone ash and plasma samples. In addition, non-diffused standards were prepared with the same reagents and in the same proportions as those used to prepare the diffused standards and samples. The non-diffused standards were made to have exactly the same F concentrations as the diffused standards. Comparison of the $\mathrm{mV}$ readings demonstrated that the $\mathrm{F}$ in the diffused standards had been completely trapped and analyzed (recovery $>99 \%$ ). The $\mathrm{mV}$ potentials were converted to $\mu \mathrm{g}$ F using a standard curve with a correlation coefficient of $\mathrm{r}^{3}$ 0.99 . 


\section{STATISTICALANALYSIS}

The data are expressed as mean \pm se. Plasma, bone $\mathrm{F}$ concentrations, the acid etch depth and the ratios between surface and whole bone $\mathrm{F}$ concentrations as a function of the $\mathrm{F}$ doses administered were tested for statistically significant differences by ANOVA and Tukey's post hoc test for individual comparisons. The correlation between bone surface and whole bone F concentrations, as well as plasma and bone surface and plasma and whole bone $\mathrm{F}$ concentrations were tested using linear regression analysis. An alpha value of 0.05 was selected as the indicator for statistically significant differences.

\section{RESULTS}

Table 1 shows mean F concentrations ( \pm SE) found in the plasma $(\mu \mathrm{g} / \mathrm{mL})$, bone surface $(\mu \mathrm{g} / \mathrm{g})$ and whole bone $(\mu \mathrm{g} /$ $\mathrm{g})$, the ratio between bone surface and whole bone $\mathrm{F}$ concentration, as well as the acid etch depth when bone surface was analyzed. The F concentration ranged between $0.030 \pm 0.006$ and $0.187 \pm 0.040$ for the plasma, $610 \pm 103$ and $4,693 \pm 703$ for the bone surface and $647 \pm 69$ and $3,439 \pm 423$ for the whole bone. The ratios surface/whole bone $\mathrm{F}$ concentrations were $0.941 \pm 0.111,1.414 \pm 0.282,1.173 \pm 0.274$ and $1.377 \pm 0.181$, for groups $1,2,3$ and 4 respectively. Groups 2 and 4 differed significantly from control $(\mathrm{p}<0.01)$. The $\mathrm{F}$ concentrations in plasma and whole bone showed a significant difference among all the groups, except for group 2 compared to group 1 . For bone surface, all groups differed from each other except for group 2 compared to group 3 . The acid etch depth in control group was significantly higher than in the other groups. Although a decrease in acid etch depth was seen with increasing $F$ concentrations in the drinking water, this difference was not statistically significant among the test groups. A significant positive correlation was found between bone surface and whole bone F (Figure $\left.1, \mathrm{r}^{2}=0.94, \mathrm{p}<0.0001\right)$, as well as between plasma and bone surface $\mathrm{F}$ (Figure 2, $\mathrm{r}^{2}=0.71, \mathrm{p}<0.0001$ ) and plasma and whole bone $\mathrm{F}$ (Figure 3, $\mathrm{r}^{2}=0.74, \mathrm{p}<0.0001$ ).

\section{DISCUSSION}

$\mathrm{F}$ is widely used in Dentistry as a therapeutic agent for the control of dental caries. Due to this, when new fluoridated agents have to be tested, it is common that the volunteers are subjected to a washout period, when fluoridated products are avoided, in order to decrease plasma and salivary F levels. However, it is known that a steadystate distribution exists between the extracellular fluid and the hydration shell of bone crystallites ${ }^{12}$. The ion-rich aqueous shells are continuous with, or at least accessible to, the extracellular fluids. Presumably, $\mathrm{F}$ in this pool is rapidly exchangeable so that it can undergo net migration in either direction, depending on the relative concentrations in extracellular fluid and the hydration shells. When plasma levels fall, a net flux of $\mathrm{F}$ from the hydration shell to the extracellular fluid occurs. When plasma levels increase, a net flux of $\mathrm{F}$ from extracellular fluid to the hydration shells occurs. The results of the present study corroborate this hypothesis of steady-state distribution, since a significant correlation was found between plasma and bone surface $\mathrm{F}$ in rats exposed chronically to different $\mathrm{F}$ concentrations in the drinking water. The determination of the time needed for removal of $\mathrm{F}$ incorporated in bone is subject of an ongoing study in our laboratory. To the extent to which this steadystate relationship exists, plasma fluoride concentrations would be influenced by the fluoride concentrations in the exchangeable pool of bone. This possibility is relevant to a subject of current interest, viz., the body fluids or tissues that may be used to estimate bone F concentrations ${ }^{11,12}$. In a recent study, Corrêa Rodrigues, et al. ${ }^{5}$ (2004) using nails as biomarkers of subchronic exposure to $\mathrm{F}$ from fluoridated dentifrice could not see a reduction in nail $\mathrm{F}$ concentration when a F-free dentifrice was used, which could have been due to the fact that $\mathrm{F}$ was being released from bone after the F-free dentifrice started being used, thus preventing plasma and in turn fingernails $F$ levels from declining.

The results of the present study show a direct relationship between the $\mathrm{F}$ concentrations in the rapidly exchangeable bone compartment (surface) and the nonexchangeable inner compartment (whole). The correlation between bone surface and whole bone $\mathrm{F}$ concentrations was strong, as well as between plasma and whole bone F. This result was expected, since the animals had been exposed

TABLE 1- Mean \pm SE (range) plasma, bone surface and whole bone fluoride concentration, ratio surface/whole bone fluoride concentration and acid etch depth

\begin{tabular}{llllll}
\hline $\begin{array}{l}{[\text { F] in drinking }} \\
\text { water }(\mathbf{p p m})\end{array}$ & $\begin{array}{l}\text { Plasma } \\
(\mu \mathrm{g} / \mathrm{mL})\end{array}$ & $\begin{array}{l}\text { Bone surface } \\
(\mu \mathrm{g} / \mathrm{g})\end{array}$ & $\begin{array}{l}\text { Whole Bone } \\
(\mu \mathrm{g} / \mathrm{g})\end{array}$ & Ratio & $\begin{array}{l}\text { Etch depth } \\
(\mu \mathrm{m})\end{array}$ \\
\hline 0 (Control) & $0.030 \pm 0.002^{\mathrm{a}}$ & $610 \pm 32^{\mathrm{a}}$ & $647 \pm 22^{\mathrm{a}}$ & $0.941 \pm 0.035^{\mathrm{a}}$ & $33.65 \pm 2.95^{\mathrm{a}}$ \\
5 & $0.048 \pm 0.004^{\mathrm{a}}$ & $1,220 \pm 103^{\mathrm{b}, \mathrm{c}}$ & $808 \pm 23^{\mathrm{a}}$ & $1.414 \pm 0.089^{\mathrm{b}, \mathrm{c}}$ & $20.46 \pm 2.52^{\mathrm{b}}$ \\
15 & $0.115 \pm 0.013^{\mathrm{b}}$ & $1,646 \pm 108^{\mathrm{c}}$ & $1,414 \pm 49^{\mathrm{b}}$ & $1.173 \pm 0.086^{\mathrm{a}, \mathrm{c}}$ & $19.40 \pm 3.59^{\mathrm{b}}$ \\
50 & $0.187 \pm 0.013^{\mathrm{c}}$ & $4,693 \pm 222^{\mathrm{d}}$ & $3,439 \pm 134^{\mathrm{c}}$ & $1.377 \pm 0.057^{\mathrm{b}, \mathrm{c}}$ & $13.48 \pm 1.07^{\mathrm{b}}$ \\
\hline
\end{tabular}

*Values in the same column with the same superscript letters are not statistically significant $(p<0.05)$. 
chronically to different fluoride doses. In addition, the whole bone analyzed included surface and subsurface bone. Thus, plasma $\mathrm{F}$ seems to be a reliable indicator of bone surface and whole bone $\mathrm{F}$ levels in rats subjected to chronic $\mathrm{F}$ exposure. The extent to which this information can be transferred to humans needs further investigation. Obtaining normative values for bone $\mathrm{F}$ levels in persons with different histories of exposure to $\mathrm{F}$ is necessary and is under determination in our laboratory.

Bezerra de Menezes, et al. ${ }^{1}$ (2003) have suggested that the ratios between bone surface and whole bone $\mathrm{F}$ concentrations are more reliable biomarkers of acute lethal F exposure than is the analysis of whole bone solely. In this chronic study, the ratios were increased in the experimental groups when compared to control, indicating a faster $\mathrm{F}$ incorporation in bone surface when $\mathrm{F}$ is administered in drinking water, although group 3 (15 ppm) did not differ from control. In addition, the whole bone analyzed included a lot of surface as well as subsurface bone and the F ratios probably would have been different if we had analyzed only subsurface bone.

In the present study, when the bone surface was analyzed for fluoride, the acid etch depth was significantly reduced when $\mathrm{F}$ was added to the drinking water. However, increasing fluoride concentrations in the drinking water (from 5 to 50 ppm) did not show a significant dose-response effect on the acid etch depth. These results indicate that the presence of $\mathrm{F}$ in the drinking water made the bone surface more resistant to acid etch, since a thinner bone layer was removed under acid attack. The same could be expected when the whole bone is considered, since there was a very strong correlation between bone surface and whole bone $\mathrm{F}$ concentrations. Significant correlations were also found between plasma and bone surface, as well as between plasma and whole bone fluoride concentrations. Thus, the results suggest that both bone surface and whole bone are suitable biomarkers of chronic F exposure in rats and plasma may be used as indicator of bone fluoride levels.

\section{REFERENCES}

1- Bezerra de Menezes LM, Volpato MC, Rosalen PL, Cury JA. Bone as a biomarker for acute fluoride toxicity. Forensic Sci Int. 2003;137(2-3):209-14

2- Buzalaf MAR, Caroselli EE, Oliveira RC, Carvalho JG de, Granjeiro JM, Whitford GM. Bone surface and whole bone as biomarkers for acute fluoride exposure. J Anal Toxicol. 2005;29(8):810-3.

3- Buzalaf MAR, Caroselli EE, Oliveira RC, Granjeiro JM, Whitford GM. Nail and bone surface as biomarkers for acute fluoride exposure in rats. J Analyt Toxicol. 2004;28:249-52.

4- Clarkson J. International collaborative research on fluoride. J Dent Res. 2000;79:893-904.

5- Corrêa Rodrigues MH, Magalhães Bastos JR, Rabelo Buzalaf MA. Fingernails and toenails as biomarkers of subchronic exposure to fluoride from dentifrice in 2-3-year-old children. Caries Res. 2004;38:109-14.
6- Ericsson Y, Gydell K, Hammarskjold T: Blood plasma fluoride: an indicator of skeletal fluoride content. J Int Res Commun. 1973;1:33.

7- Fiske CH, Subarrow Y. The colorimetric determination of phosphorus. J Biol Chem. 1925;66:375-400.

8- Parkins FM, Tinanoff N, Moutinho M, Anstey MB, Waziri MH: Relationships of human plasma fluoride and bone fluoride to age. Calcif Tiss Res. 1974;16:335-8.

9- Taves DR. Determination of submicromolar concentrations of fluoride in biological samples. Talanta. 1968;15:1015-23.

10- Taves DR, Guy WS: Distribution of fluoride among body compartments; in Johansen E, Taves DR, Olsen TO (eds): Continuing Evaluation of the Use of Fluorides; AAAS Selected Symposium 11. Boulder CO, Westview Press; 1979. p. 159-85.

11- Whitford GM. Fluoride in dental products: safety considerations. J Dent Res. 1987;66:1056-60.

12- Whitford GM. Intake and metabolism of fluoride. Adv Dent Res. 1994;8:5-14. 